\title{
First recovery of Candida africana from the oral cavity of children with leukaemia receiving chemotherapy in Basrah, Iraq
}

\author{
Hanan Makiia ${ }^{1}$, Abdullah Al-Saadoonb ${ }^{1}$, ADNAN Al-Hawash ${ }^{2}$, and Awatif Issa ${ }^{1}$ \\ ${ }^{1}$ Affiliation not available \\ ${ }^{2}$ University of Basrah
}

May 6, 2020

\begin{abstract}
Twenty-nine Candida isolates were assessed with green-coloured colonies using CHROMagar Candida medium with a positive germ-tube test. Based on morphological and biochemical tests, 29 strains were isolated from the oral cavity of children with leukaemia who were undergoing chemotherapy in Basrah, Iraq. Three (10.3\%) of them were identified as Candida africana. Identification of the isolated yeasts was further confirmed at the molecular level by amplifying the internal transcribed spacer sequencing (ITS) region of rDNA comprising the ITS1-5.85-ITS2 regions of fungal rRNA genes. This study represented the first recovery of C. africana from the oral cavity for immunocompromised patients with leukaemia and considered the first record of species in Iraq.
\end{abstract}

\section{Introduction}

Candida africana was originally isolated from patients in Africa and Germany in 1993 as atypical Candida albicans strains [1]. Later, Tietz et al. [2] proposed it as a new species. Since 2001, the new species was reported in several countries in the Middle East [3-5], Europe [6-9], East Asia [10-14], South America [10,15,16], Africa [17-19], and North America [20, 21]. In addition, C. africana was primarily isolated from the genital specimens but rarely from the skin [2], from blood cultures (in Chile [10]), and from systemic infection with renal involvement in preterm newborn babies (in the United States [21]). In Turkey, reexamining 195 vaginal C. albicans strains using hyphal wall protein 1 (HWP1) gene polymorphism proved that none of them were Candida dubliniensis or C. africana [22]. Similarly, in Malaysia, 98 C. albicans isolates were recovered from the vagina, but none of them were found to be C. africana [23].

Candida albicans possesses a highly dynamic genome that is subjected to a wide range of changing, resulting in the evolution of new variants or strains. As an example of such evolution, C. albicansshaped the emergence of $C$. africana as a new species that is characterised by lower virulence and the inability to produce chlamydospores. Extensive molecular analysis of a panel of $C$. albicans that were recovered from vaginal swabs revealed several characteristics that distinguished those re-examined strains from the C. albicans, such as lacking $\mathrm{N}$-acetylglucosamine assimilation due to a typical polymorphism in HXK1, which compromised the utilisation of this amino acid. In addition, multi-locus sequencing analysis showed significant differences between those strains and $C$. albicans and demonstrated a high probability of variation, which suggests that this is an adequate type to study evolution. As a result, Chowdhary et al. [24] and Giosa et al. [25] positioned them in a separate species called C. africana .

The Candida species were extensively studied in Iraq, focusing on the clinically related ones, which were isolated from different parts of the human body [26-36]. Despite that, this work is considered the first record of this species in Iraq from the oral cavities of leukaemia patients.

\section{Materials and Methods}




\section{Ethics statement}

Committees from the following institutes approved the sampling that is required to achieve this study: Research and Knowledge Unit, Training and Development of Personnel Division in Planning, the Basrah Children's Specialty Hospital, and the Resource Development Department of the Basra Health Department in Basrah Governorate, Iraq. We gained written agreement from the parents or guardians of the children after a detailed explanation of the goals of our research. We are ethically committed not to breach the privacy of the patient's family or physically harm the patients, as all sampling was conducted under the care of a physician.

Oral swabs were collected from 25 children with leukaemia (age range 2-16 years old) who were hospitalised in the Basrah Children's Specialty Hospital, Basrah Province, southern Iraq, during the period from August 2016 to June 2017. The samples were immediately spread on a Sabouraud dextrose agar supplemented with $50 \mathrm{mg} / \mathrm{L}$ of chloramphenicol. The petri dishes were incubated at $37^{\circ} \mathrm{C}$ for $48 \mathrm{~h}$. Identification of the growth strains was performed through several traditional tests, including the germ-tube test [37], a test of the ability to produce chlamydospores on corn-meal agar (HiMedia, India) with $1 \%$ Tween 80 [38] with growth at $30^{\circ} \mathrm{C}$, $37^{\circ} \mathrm{C}$, and $42^{\circ} \mathrm{C}$ [15], a test of the colony appearance and colour on CHROMagar (Paris, France), [39] and the detection of carbohydrate assimilation using the API 20c system (bio Merieux Marcy IE toile, France) [15].

\section{Molecular Identification}

The DNA was extracted from the isolated yeasts using the genomic DNA extraction mini kit (Favor Prep ${ }^{\mathrm{TM}}$ Fungi/Yeast Genomic DNA-Canada). The extracted DNA was migrated using agarose gel electrophoresis. The PCR amplification was performed in a final volume of $25 \mu \mathrm{l}$. Each reaction consists of $12.5 \mu \mathrm{l}$ of Green Master Mix, $0.5 \mu \mathrm{l}$ of $\mathrm{MgCl}_{2}, 0.5 \mu \mathrm{l}$ of each forward (ITS1,F'5-TCC GTA GGT GAA CCT GCG G-'3) and reverse (ITS4, R-5' TCC GCT TAT TGA TAT GC-'3) primer, and $1.5 \mu \mathrm{l}$ of the template DNA. The reaction volume was completed to the final volume with $9.5 \mu$. The thermal cycles were programmed as follows: an initial denaturation step at $94^{\circ} \mathrm{C}$ for $5 \mathrm{~min}$, a second step of 25 denaturation cycles at $94^{\circ} \mathrm{C}$ for $30 \mathrm{~s}$ of annealing at $56^{\circ} \mathrm{C}$ for $45 \mathrm{~s}$, and extraction at $72^{\circ} \mathrm{C}$ for 1 min with a last step at $72^{\circ} \mathrm{C}$ for 7 min. The amplified products were visualised using $0.8 \%$ agarose gel electrophoresis in the TBE buffer and then stained with $0.2 \mu \mathrm{l}$ of ethidium bromide and photographed [40]. The PCR products of the isolated strains were sent to Macrogen Company (hhtt://dna. Macrogen. Com, South Korea) for sequencing.

\section{Results and Discussion}

Out of the 29 Candida strains that were recovered from the oral cavity of male and female children with leukaemia before and after chemotherapy, three isolates (10.3\%) were identified as C. africana based on morphological, biochemical, and molecular features.

As shown in Table 1, the ICL21 isolate was obtained from the oral cavity of a 5.5-year-old female with acute lymphoblastic leukaemia (ALL) after receiving chemotherapy. Before induction, there was no signs of infection with candidiasis, as the culture of the concerned sample was negative. The ICL26 was isolated from oral swabs taken from a 10-year-old male afflicted with acute myeloid leukaemia (AML) after chemotherapy. The patient showed the typical oral signs and symptoms, including pseudomembranous candidiasis on the tongue and diffused painful erythematous mucositis. Unfortunately, this patient died after 9 months of chemotherapy. The third isolate ICL27 was recovered from the oral Candida growth of a 2.8-year-old male suffering from ALL before having any course of chemotherapy.

All patients were examined thoroughly by the physicians and subjected to a specific protocol of chemotherapy including methotrexate (MTX), 6-mercaptopurine (6MP), and vincristine (VCR).

Developing such diverse and frequent oral yeast infections and mucositis is attributed to the chemotherapy courses, which increases the number and diversity of such infections [41, 42]. Various prophylactic sched- 
ules, including oral hygiene, Mycostatin droplets, and chlorohexidine, may be considered to reduce oral opportunistic pathogens [43-45].

To our knowledge, the present findings represent the first recovered C. africana isolates from the oral cavity of immunocompromised patients with leukaemia, and the first report of the species in Iraq. To date, the majority of $C$. africana isolates have been registered from female genital samples. However, it has also been reported in other sites of the human body $[2,10,21,12]$.

Similar to Romeo and Criseo [46], our data showed that C. albicans was the most frequent species that comprised $89.6 \%$ of the strains, followed by $C$. africana at $10.3 \%$. This study did not recover any $C$. dubliniensis strains, which is a clear contradiction with the findings by Romeo and Criseo [46].

The present isolates of $C$. africana possess several diagnostic features that distinguish them from other typical strains of $C$. albicans. These phenotypic characteristics are shown in Table 2, including negative results for chlamydospore on corn-meal agar with $1 \%$ Tween 80 , no growth at $42^{\circ} \mathrm{C}$, the inability to assimilate the amino sugars $\mathrm{N}$-acetylglucosamine and glucosamine as well as trehalose and DL-lactate, and small, bluish-green colonies on the CHROMagar (Fig. 1A).

These results agree with those obtained by previous studies $[2,3,5,7-9]$. However, our C. africana isolates are associated withC. albicans in the positive germ-tube formation, growing well at $30^{\circ} \mathrm{C}$ and $37^{\circ} \mathrm{C}$. These features are identical to those described by Tietz et al. [2], Romeo and Criseo [8, 47], and Borman et al. [9]. Colonies of C. africana grow well on Sabouraud dextrose agar at $28^{\circ} \mathrm{C}$, as small cream-coloured (Fig. 1B). pseudohyphae are rare.

Specific universal primers for Candida strains were employed to amplify the ITS1-5.8S-ITS2 regions of rDNA genes, giving the PCR product a molecular size of $572 \mathrm{bp}$ (Fig. 2). Nonetheless, comparing all sequences that were obtained in this study with the database of GenBank and CBS revealed that three (10.34\%) out of 29 isolates were identified as C. africana, and they showed $>99 \%$ sequence similarity with that of the C. africana strain (CBS 8781), while the rest of the isolates (89.65\%) belonged to C. albicans, which were mostly analogous to the strain C. albicans (ATCC 18804).

In addition to the phynotypic similarities between C. africanaand other species of C. albicans complex, there was a high percentage of molecular proximity among them. Therefore, based on several reports and the sequencing of the D1-D2 regions, the C. africana was considered a variant and was not discriminated from the C. albicans species complex because the level of dissimilarity was too small to be a distinct species $[7,8,47,49]$. However, several investigators showed that molecular diagnostic methods, such as sequencing the internal transcribed spacer region 2 or the PCR amplicon length of the HWP1 could be used for definitive identification of $C$. africana $[9,12,14,16,48,50]$, while Rodriguez-Leguizmon et al. [15] indicated that the identified isolates based on sequencing the D1-D2 region of the rDNA and the HWP1 gene were in agreement with those for C. albicans. Therefore, their study recommended using the matrix-assisted laser desorption-ionisation time of flight mass spectrophotometry (MALDI-TOF MS) and phenotypic and molecular identification to separate the three species of C. albicans, C. africana, and C. dubliniensis.

In our study, the isolation of $C$. africana in the oral cavity of the patients with leukaemia was not expected because it has been documented that the species is common in human genital organs, particularly in vaginal samples $[1-3,7,9,10,18,20,21,47,49]$. However, it was possible to use genes and more to separate this species from $C$. albicans. In contrast to local and international studies regarding C. dubliniensis, which primarily occurs in the oral cavity $[8,51,52]$, the techniques employed in this work did not show the presence of this species. Abdul-Raheem [32] and Aldossary et al. [36] recovered this species from the oral cavity of diabetic and cancer patients, respectively. Therefore, isolating $C$. africana from the oral cavity is a surprising finding, as it is the first study reporting the presence of C. africana in the oral cavities of immunocompromised patients. Candida africana has been reported from Saudi Arabia (west border of Iraq) [3] and recently from Iran (east border of Iraq) $[4,5]$ as an etiological agent of vulvovaginal candidiasis, while it was absent in all re-examined vaginal specimens in Turkey [22]. Hence, the present findings represent the first report of $C$. africana from the oral cavity of immunocompromised patients with leukaemia receiving chemotherapy and 
the first record of the species in Iraq. However, further epidemiological, clinical, phenotypical, and molecular inspections based on a larger sample size are strongly recommended to uncover the actual recrudescence of C. africana in clinical specimens.

Disclosure statement: The authors declare that they have no conflicts of interest

Acknowledgements The authors wish to thank all the children and their parents for their generous cooperation with us during the sample collection. We extend a sincere thanks to the staff of Basrah Children's Specialty Hospital for their kind help and facilities

\section{References}

1 Tietz HJ, Küssner A, Thanos M, et al. Phenotypic and genotypic characterization of unusual vaginal isolates of Candida albicansfrom Africa. J Clin Microbiol. 1995; 33: 2462-5.

2 Tietz HJ, Hopp M, Schmalreck A, Sterry W, Czaika V. Candida africana sp. nov., a new human pathogen or variant of Candida albicans? Mycoses. 2001; 44:437-45.

3 Al-Hadaithy SSA, Fotedar R. Recovery and studies on chlamydospore-negative Candida albicans isolated from clinical specimen. Med Mycol.2002; 40: 301-6.

4 Yazdanparast SA, Khodavaisy S, Fakhim H, et al. Molecular characterization of highly susceptible Candida africana from vulvovaginal candidiasis Myycopathologia. 2015; 180: 317-323.

5 Seifi Z, Mahmoudabadi AZ, Halvaeezadeh M. Candida africana, a first case from Iran, susceptibility to antifungals, evaluation extracellular enzymes and biofilm formation. IJAPBS. 2015; 4: 75-80.

6 Mendling W, Krauss C, Fladung B. A clinical multicenter study comparing efficacy and tolerability of topical combination therapy with clotrimazole (Canesten, two formats) with oral single dose fluconazole (Diflucan) in vulvovaginal mycoses. Mycoses. 2004; 47: 136-42.

7 Alonso-Vargas R, Elorduly L, Eraso E, et al. Isolation of Candida africana, probable atypical strains of Candida albicans, from a patient with vaginitis. Med Mycol. 2008; 46: 167-70.

8 Romeo O, Criseo G. Morphological, biochemical and molecular characterisation of the first Italian Candida africanaisolate. Mycoses. 2009; 52:454-57.

9 Borman AM, Szekely A, Linton CJ, Palmer MD, Brown P, Johnson EM. Epidemiology, antifungal susceptibility, and pathogenicity of Candida africana isolates from the United Kingdom. J Clin Microbiol. 2013; 51:967-72.

10 Odds FC, Bougnoux ME, Shaw DJ, et al. Molecular phylogenetics of Candida albicans . Eukaryotic Cell. 2007; 6: 1041-52.

11 Shan Y, Fan S, Liu X, Li J. Prevalence of Candida albicans -closely related yeasts, Candida africana and Candida dubliniensis in vulvovaginal candidiasis. Med Mycol. 2014; 52: 636-40.

12 Sharma C, Muralidhar S, Xu J, Meis JF, Chowdhary A. Multilocus sequence typing of Candida africana patients with vulvovaginal candidiasis in New Delhi, India. Mycoses. 2014; 67: 544-52.

13 Song ES, Shin JH, Jang HC, et al. Multilocus sequence typing for the analysis of clonality among Candida albicans strains from a neonatal intensive care unit. Med Mycol. 2014; 52: 653-658.

$14 \mathrm{Hu}$ Y, Yu A, Chen X, Wang G, Feng X. Molecular characterization of Candida africana in genital specimens in shanghai, China. Biomed Res Int. 2015 185387. Doi: 10.1155/2015/185387.

15 Rodríguez-Leguizamón G, Fiori A, López LF, et al. Characterising atypical Candida albicans clinical isolates from six third-level hospitals in Bogotá, Colombia. BMC microbial. 2015; 15:199. doi: 10.11866/s 12866-015-0535-0. 
16 Theill L, Dudiuk C, Morano S, et al. Prevalence and antifungal susceptibility of Candida albicans and its related species Candida dubliniensis and Candida africana isolated from vulvovaginal samples in a hospital of Argentina. Rev Argent. Microbiol. 2016; 48: 43-49.

17 Dieng Y, Sow D, Ndiaye M, et al. Identification of threeCandida africana strains in Senegal. J Mycologie Med. 2012; 22: 335-40.

18 Nnadi NE, Ayanbimpe GM, Scordino F, et al. Isolation and molecular characterization of Candida africana from Jos, Nigeria. Med Mycol. 2012; 50:765-7.

19 Ngounana TK, Krasteva D, Drakulovski P, et al. Investigation of minor species Candida africana, Candida stellatoidea and Candida dubliniensis in the Candida albicans complex among Yaounde (Cameroon) HIV-infected patients Mycoses. 2015; 58: 33-9.

20 Hazen K. Novel yeast, originally detected in Africa, now isolated from weman in the United States In: The

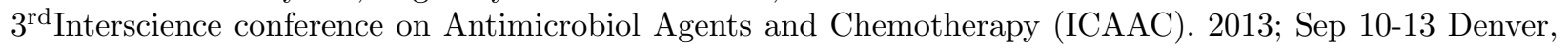
Co, USA.

21 Romeo O, Tietz HJ, Criseo G. Candida africana : is it a Fungal Pathogen? Curr Fungal Infect Rep. 2013; 7: $192-7$.

22 Gumral R, Sancak B, Guzel AB, SaraçhMA, Ilkit M. Lack ofCandida africana and Candida dubliniensis in vaginalCandida albicans isolates in Turkey using HWP1 gene polymorphisms.Mycopathologia. 2011; 172: 73-6.

23 Yazdanpanah A, Khaithir TM. Issues in identifying germ tube positive yeasts by conventional methods. J. Clin Lab Anal. 2014; 28: 1-9.

24 Chowdhary A, Hagen F, Sharma C, et al. Whole genome-based amplified length polymorphism analysis reveals genetic diversity in Candida africana . Frontiers Microbiol. 2017; 8: 1-8.

25 Giosa D, Felice MR, Lawrence TJ, et al. Whole RNA-sequencing and transcriptome assembly of Candida albicans and Candida africana under chlamydospore-inducing conditions. Genome Biol. Evol. 2017; 9(7): 1971-77.

26 Al-Duboon AH. The etiological agents of Otomycosis in Basrah (Iraq). Basrah J Sci. 2000; 18(2): 1-6.

27 Abdullah SK, Khudor MH, Al-Salman M. The role of some predisposing and risk factors in incidence of vulvovaginal candidiasis in Basrah women. Basrah J Sci. 2001; 19(1): 25-34.

28 Khudor MH, Al-Salman M, Abdullah SK. Incidence and species distribution of vaginal yeasts in Basrah women. Iraq J Biol. 2002; 2(2): 212-19.

29 Khudor MH, Abdullah SK, Al-Salman M. Incidence of Candida and other yeasts in urine of asymptomatic pregnant women in Basrah city. Basrah J Sci. 2000; 20(1): 47-52.

30 Muhsin TM, Al-Duboon AH, Al-Rubaiy KK. Cutaneous candidiasis from Basrah, Iraq. Iraqi J Biol. 2003; 3(1): 135-39.

31 Al-Abbasi AM, Al-Saadoon AH, Sabbar BA. Otomycosis in Basrah-Iraq. JABHS. 2011; 12(2): 28-33.

32 Abdul-Raheem BS. A study on occurrence of Candida species in the oral cavity of diabetic patients in Basrah. M. Sc. Thesis. College of Science, University of Basrah. 2012; 104pp.

33 Alrubayae I, Al-Duboon AH, Majed M. Study of Candida spp. associated with urinary tract infections in Basra: Urinary tract infection associated with Candida spp.: Their identification, pathogenicity and susceptibility to antifungals. Lambert Acad. Pub. 2013; 224pp.

34 Hasan AM, Al-Jubouri MH. Isolation of Candida spp. from patients with different types of Leukemia who suffered oral candidiasis due to their weekend immune system. J Pharm Chem Biol Sci. 2015; 3(1):79-83. 
35 Mohammed BL, Bander KI, Hamad TA. Determine phospholipase and aspartic proteinases activity as virulence factors in Candidaspecies isolated from vaginal infection in Kirkuk City. Worl J Pharm Pharmaceut Sci. 2015; 4(12): 260-273.

36 Aldossary MA, Almansour NA, Abdulraheem BS. Isolation and identification of Candida species from the oral cavity of cancer patients undergoing chemotherapy in Basrah, Iraq, J Biol Agri Health Care. 2016; $6(18): 22-30$

37 Williams DW, Lewis MAO." Isolation and identification of Candida from the oral cavity". Oral Diseases. 2000; 6: 3-11.

38 Marsh PD, Martin M. "Oral fungal infections," in Oral Microbiology, Churchill Livingstone, Edinburgh, UK, 2009;166-179.

39 Odds FC, Bernaerts R. CHROMagar Candida, a new differential isolation medium for presumptive identification of clinically important Candida species. J Clin Microbiol. 1994; 32: 1923-29.

40 Mirhendi H, Makimura K, Khoramizadeh M, Yamaguchi H. A one-enzyme PCR-RFLP assay for identification of six medically important Candida species. Jpn J Med Mycol. 2006; 47: 225-29.

41 Levy-Polack MP, Sebelli P, Polack NL.Incidence of oral complications and application of a preventive protocol in children with acute leukemia. Spec Care Dentist. 1998; 18(5): 189-93.

42 Al-Abeid HM, Abu-Elteen KH, Elkarmi AZ, Hamad MA. Isolation and characterization of Candida spp. in Jordanian cancer patients: Prevalence, pathogenic determinants, and antifungal sensitivity. Jpn J Infect Dis. 2004; 57: 279-84.

43 Cheng KK, Chang AM, Yuen MP. Prevention of oral mucositis in paediatric patients treated with chemotherapy; a randomised crossover trial comparing two protocols of oral care. Eur J Cancer. 2004; 40(8): 1208-16.

44 Pereira Pinto L, de Souza LB, Gordón-Núñez MA, et al. Prevention of oral lesions in children with acute lymphoblastic leukemia. Int J Pediatr Otorhinolaryngol. 2006; 70(11): 1847-51.

45 Chi AC, Neville BW, Krayer JW, Gonsalves WC. Oral manifestations of systemic disease. American Fam Physi. 2010; 82(11):1381-88.

46 Romeo O, Criseo G. Molecular epidemiology of Candida albicansand its closely related yeasts Candida dubliniensis and Candida africana. J Clin Microbiol. 2009; 47:212-4.

47 Romeo O, Criseo G. Candida africana and its closest relatives. Mycoses. 2011; 54:475-86.

48 Romeo O, Criseo G. First molecular method for discriminating between Candida africana, Candida albicans and Candida dubliniensis by using hwp1 gene. Diagn Microbiol Infect Dis. 2008; 6:230-3.

49 Odds FC. Molecular phylogenetics and epidemicology of Candida albicans. Future Microbiol. 2010; 5:6779.

50 Criseo G, Scordino F, Romeo O. Current methods for identifying clinically important cryptic Candida species. J Microbiol Methods 2015; 111:50-56.

51 Sullivan DJ, Westerneng TJ, Haynes KA, Bennett DE, Coleman DC.Candida dubliniesis sp. nov. : Phenotypic and molecular characterization of a novel species associated with oral candidiasis in HIV-infected individuals. Microbiology. 1995; 141:1507-21.

52 Marsh PD, Martin M. "Oral fungal infections", in Orals Microbiology, Churchill Livingstone, Edinburgh, UK; 2009. pp. 166-179.

Figures captions 
1- Fig. 1 Culture of Candida africana (1) and Candida albicans (2) on CHROMagar (A) and Sabouraud dextrose agar (B). 2- Fig. 2 Gel electrophoresis of the amplified rDNA internal transcribed sequence region of Candida species. Amplified PCR products were migrated on 0.8 agarose at 50 volts for 40 min. Lane M: ladder (100 bp DNA marker). Lane 1: Candida albicans ATCC 18804 and lanes 2-4 C. africana strains.

\section{Hosted file}

Figures.docx available at https://authorea.com/users/318640/articles/448573-firstrecovery-of-candida-africana-from-the-oral-cavity-of-children-with-leukaemia-receivingchemotherapy-in-basrah-iraq

\section{Hosted file}

Tables.docx available at https://authorea.com/users/318640/articles/448573-firstrecovery-of-candida-africana-from-the-oral-cavity-of-children-with-leukaemia-receivingchemotherapy-in-basrah-iraq 